\title{
Biosorption of Remazol Brilliant Blue R Dye onto Chemically Modified and Unmodified Yarrowia lipolytica Biomass
}

YUSUF DORUK ARACAGÖK ( $\sim$ doruk@hacettepe.edu.tr )

Hacettepe Üniversitesi Fen Fakültesi https://orcid.org/0000-0002-0354-0817

\section{Research Article}

Keywords: Biosorption, Remazol brilliant blue R, Dye removal, Biomass

Posted Date: November 9th, 2021

DOI: https://doi.org/10.21203/rs.3.rs-1010620/v1

License: (c) (1) This work is licensed under a Creative Commons Attribution 4.0 International License.

Read Full License

Version of Record: A version of this preprint was published at Archives of Microbiology on January 8th, 2022. See the published version at https://doi.org/10.1007/s00203-021-02743-3. 
1 Biosorption of Remazol Brilliant Blue R Dye onto Chemically Modified and Unmodified Yarrowia

2 lipolytica Biomass

\title{
Y. Doruk ARACAGÖK
}

Department of Biology, Faculty of Science, Hacettepe University, 06800 Beytepe, Ankara, Turkey.

\author{
E-mail:doruk@hacettepe.edu.tr
}

ORCID: 0000-0002-0354-0817

\section{Abstract}

Remazol Brilliant Blue R (RBBR) is a widely used carcinogenic and toxic dye. This study focused on RBBR dye from aqueous solution using potassium permanganate, cetyltrimethylammonium bromide (CTAB) modified, and unmodified Yarrowia lipolytica biomass as biosorbent. RBBR dye biosorption studies were carried out as a function of $\mathrm{pH}$, initial dye concentration, biosorbent dose, contact time, and temperature. The $\mathrm{pH}$ of the aqueous solution strongly influenced the biosorption percent of RBBR dye. The highest dye biosorption capacity yield was obtained at pH 2-3 as well as above $\mathrm{pH}$ 3, very low yield biosorption of RBBR was observed. No differences were found between chemically modified and unmodified biomass in terms of RBBR dye biosorption capacity. In the first $15 \mathrm{~min}$, almost 50\% RBBR dye was removed from the solution and reached equilibrium within,180 min at $\mathrm{pH}$ 2. Biosorption isotherm obeyed Langmuir isotherm model and pseudo-secondorder kinetic model.

Keywords: Biosorption, Remazol brilliant blue R, Dye removal, Biomass

\section{Introduction}

Thousands of synthetic dyes have been developed and used in industrial applications since the first discovery in 1856 by William Henry Perkin(Jianlong 2002; Saratale and Chang 2011). Dyes are widely used in many industrial applications such as manufacturing, plastics, food processing, printing, and cosmetics. Discharge of dyecontaining industrial effluents into aquatic environments causes serious health problems and pollution of water sources. Some dyes have detrimental effects on human health such as dysfunction of the reproductive system, liver, brain, kidney, and central nervous system (Yagub et al. 2014). Remazol Brilliant Blue R (RBBR) also known as Reactive Blue 19 is an anthraquinone dye (Trivedi et al. 2009). Remazol Brilliant Blue R used in the textile industry and as the starting agent for the manufacture of polymeric materials is highly toxic, carcinogenic, and hazardous to aquatic organisms (Mate and Mishra 2020) The chemical structure of the reactive dyes leads to low biodegradability and recalcitrant characteristics. Therefore, it is crucial to treat reactive dyes containing effluents before discharge to surrounding environments (Yagub et al. 2014).

Several physical and chemical methods are used to remove dyes from water bodies such as ozonation, electrochemical oxidation, photocatalytic oxidation, and adsorption (Novotnýeněk et al. 2001; Liu et al. 2015). Adsorption refers to a process in which a gas or substance dissolved in liquid accumulates on the surface of a solid or liquid to form a molecular or atomic film. (El-Naas and Alhaija 2013). Adsorption is an effective method for the removal of heavy metals, dyes, pharmaceuticals, and other toxic substances (Rao and Viraraghavan 2002; Kumar et al. 2006; Fan et al. 2008; Hasan et al. 2012; Jung et al. 2013). Adsorption is a useful technique due to its ease of application, low cost, and no secondary waste generation (Zheng et al. 2021). 
The use of activated carbon in adsorption-based removal of organic compounds is the first choice due to its excellent adsorption efficiency, however, the use of commercial activated carbon is limited due to its high cost (Gad and El-Sayed 2009). Consequently, researchers have focused on finding novel and efficient adsorbents.

In this regard, previous studies showed that agro-based materials, chitin, peanut hull, algal, and fungal biomass can be used as alternative adsorbents for removing unwanted substances from aqueous solutions (GONG et al. 2005; Luo 2006; Xiong et al. 2010; Mohamed et al. 2015; Ayub et al. 2019).

Fungal biomass is used to remove dyes from aqueous solutions (Xiong et al. 2010; Salvi and Chattopadhyay 2016). A significant amount of biomass can be obtained inexpensively from yeasts (Jianlong 2002). Yarrowia lipolytica (Fig. 1) is an aerobic, dimorphic yeast is used in various industrial applications such as the production of citric and isocitric acid, proteases, lipases, biosurfactants, and fruit aroma (Gonçalves et al. 2014). We think it is important to demonstrate the use of biomass obtained from this yeast, which has a wide range of industrial applications, in removing environmental pollutants. Therefore, in this study, chemically modified and unmodified yeast biomass was investigated in terms of RBBR biosorption capabilities.

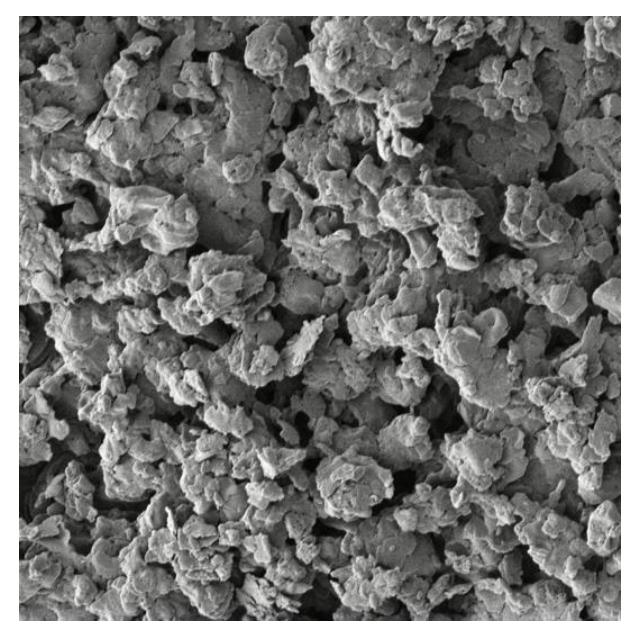

Figure 1. Scanning electron micrograph of the Yarrowia lipolytica cell surface

\section{Materials and Methods}

\subsection{Chemicals and microorganism}

Remazol Brilliant Blue R (CAS Number: 2580-78-1), cetyltrimethylammonium bromide (synonym: CTAB, CAS Number: 57-09-0), and potassium permanganate (CAS Number: 7722-64-7) were obtained from Sigma-Aldrich. Yarrowia lipolytica NBRC 1658 strain was used to obtain biomass. Fungal species were kept on sabroud dextrose agar for up to 20 days at $4{ }^{\circ} \mathrm{C}$ in the refrigerator and transferred to a fresh solid media, periodically.

\subsection{Production of biomass}

Yarrowia lipolytica cells were inoculated into $1000 \mathrm{ml}$ Erlenmeyer flasks containing $500 \mathrm{ml}$ malt extract broth


filtrated by filter paper and washed three times with distilled water. After filtration, fungal biomass was autoclaved at $110^{\circ} \mathrm{C}$ for $25 \mathrm{~min}$ and left to dry for 2 days at $40^{\circ} \mathrm{C}$. Dried and heat-inactivated biomass ground into a powder and sieved through a screen $(0,15 \mathrm{~mm})$. 


\subsection{Chemical modification methods}

\section{CTAB treatment:}

Three hundred milligrams of heat-inactivated biomass were added into $25 \mathrm{ml} \mathrm{C} \mathrm{TAB}$ solution $(1.5 \% \mathrm{w} / \mathrm{v})$ and incubated at $30^{\circ} \mathrm{C}$ for $24 \mathrm{~h} \mathrm{(150} \mathrm{rpm)} \mathrm{(Huang} \mathrm{et} \mathrm{al.} \mathrm{2016).} \mathrm{After} \mathrm{24h} \mathrm{incubation} \mathrm{period} \mathrm{biomass} \mathrm{was} \mathrm{separated} \mathrm{by}$ filtration, the filtrate was washed with $1 \mathrm{~L}$ distilled water. After the washing process modified biomass left to dry $48 \mathrm{~h}$ at $40^{\circ} \mathrm{C}$ and sieved through a $0.15 \mathrm{~mm}$ screen.

\section{Potassium permanganate treatment:}

Heat-inactivated yeast biomass $\left(300 \mathrm{mg}\right.$ ) was oxidized with $10 \mathrm{mM}$ solution of potassium permanganate at $30{ }^{\circ} \mathrm{C}$ for $30 \mathrm{~min}$ (Luo 2006). At the end of $30 \mathrm{~min}$ modified biomass was separated by filter paper, washed with distilled water $(1 \mathrm{~L})$, and left to dry $\left(48 \mathrm{~h}, 40^{\circ} \mathrm{C}\right)$. After that sieved through a $0,15 \mathrm{~mm}$ screen.

\section{4 Characterization}

The surface morphology of Yarrowia lipolytica was monitored with GAIA3 + Oxford XMax 150 EDS scanning electron microscope.

Unmodified biomass and modified biomass samples were characterized spectroscopically by Nicolet IS50 FTIR spectrophotometer (Thermo Scientific). All spectra were recorded between 4000 and $400 \mathrm{~cm}-1$ wavenumber regions.

The change in the surface areas of the obtained biomass and modified biomass was followed with the Tristar II (Micromeritics) model device.

104

105

\subsection{Biosorption experiments}

$10915 \mathrm{ml}$ tubes and treated with $10 \mathrm{ml}$ of dye solution.

110 The tubes containing the dye solution and adsorbent were shaken horizontally at $150 \mathrm{rpm}\left(25^{\circ} \mathrm{C}\right)$. To determine 111 suitable conditions for dye removal, the effect of $\mathrm{pH}(2-7)$, amount of adsorbent (250-2500 mg/L), initial dye concentration $(25-175 \mathrm{mg} / \mathrm{L})$, temperature $\left(+4-30^{\circ} \mathrm{C}\right)$, and contact time were investigated. The biomasses were separated via a syringe filter and the change in the RBRR concentration was measured with a spectrophotometer (Shimadzu UV-1700) at $592 \mathrm{~nm}$ wavelength. 
122

where $C_{i}$ is the RBRR concentration before adsorption and $C_{f}$ is the final RBRR concentration after adsorption, $m$ is the amount of fungal biomass $(\mathrm{g})$ and $\mathrm{V}$ is the reaction medium $(\mathrm{L})$.

\subsection{Isotherms}

In this study, two widespread used adsorption models, i.e., Freundlich and Langmuir isotherms, were employed to describe RBBR adsorption. Isotherm plots were drawn via R studio with a PUPAIM adsorption package.Linearized Langmuir and Freundlich models are expressed with following equations (Freundlich 1907; Langmuir 1918).

Langmuir: $Q_{e}=Q_{\max } K_{L} C_{e} /\left(1+K_{L} C_{e}\right)$ eq.(3)

Freundlich $: \log _{Q e}=\log K_{F}+1 / n \log C_{e}$ eq. (4)

Where $\mathrm{C}_{\mathrm{e}}(\mathrm{mg} / \mathrm{L})$ is the concentration at equilibrium, $\mathrm{q}_{\mathrm{e}}(\mathrm{mg} / \mathrm{g})$ is the adsorption capacity at equilibrium, $K_{L}(\mathrm{~L} / \mathrm{g})$ is the adsorption strength, $\mathrm{q}_{\mathrm{m}}(\mathrm{mg} / \mathrm{g})$ is the maximum adsorption capacity, $\mathrm{K}_{\mathrm{F}}$ is the adsorption coefficient, and $1 / \mathrm{n}$ is the adsorption index.

Langmuir isotherm dimensionless constant separation factor $\left(R_{L}\right)$ was used to determine the favorability of the adsorption. The values of dimensionless separation factor indicate the type of adsorption to be favorable $\left(0<R_{L}<\right.$ 1), unfavorable $\left(1>R_{L}\right)$ or linear $\left(R_{L}=0\right)$.

$R_{L}=1 /\left(1+K_{L} C\right)$

eq. (5)

\subsection{Kinetics}

The pseudo-first-order and pseudo-second-order kinetic models were tested for the biosorption of Remazol Brilliant Blue R dye on biomass. The pseudo-first-order model was calculated according to the Lagergren equation (Lagergren 1898).

$\ln \left(q_{e}-q_{t}\right)=\ln (q e)-K_{l} t$

The pseudo-second order kinetic model that is proposed as (Ho and McKay 1999):

$t / q_{t}=1 /\left(K_{2} q_{e}^{2}\right)+t / q_{e}$ eq. (7)

\section{Results and discussion}

\subsection{Characterization}

BET surface areas unmodified, CTAB modified, and potassium permanganate modified were found to be 0,3630 $\mathrm{m}^{2} / \mathrm{g}, 0,3947 \mathrm{~m}^{2} / \mathrm{g}, 3,5686 \mathrm{~m}^{2} / \mathrm{g}$, respectively. A previous study showed that modification of fungal biomass with CTAB, increases bet surface area 1.5 to $2.03 \mathrm{~m}^{2} / \mathrm{g}$ which means CTAB modification caused $26 \%$ increase in BET surface area (Huang et al. 2016). . In our study, modification with CTAB increased by only $8 \%$. 
FTIR spectra of unmodified (A), CTAB modified (B) and $\mathrm{KMNO}_{4}(\mathrm{C})$ modified biomass are shown in Fig. 2. For all sample spectra, the strong broadband ranging from 3600 to $3100 \mathrm{~cm}^{-1}$ may cause by the overlap of $\mathrm{NH}$ and $\mathrm{OH}$ stretching vibrations. The bands between 3000 and $2800 \mathrm{~cm}^{-1}$ are the $\mathrm{CH}$ stretching vibrations of the $-\mathrm{CH} 3$ and $>\mathrm{CH} 2$ functional groups of fatty acids found in membrane phospholipids. Peaks at $1744 \mathrm{~cm}^{-1}$ (A), $1743 \mathrm{~cm}^{-1}$ (B), and $1743 \mathrm{~cm}^{-1}(\mathrm{C})$ may be attributed to $\mathrm{C}=\mathrm{O}$ stretching vibrations of lipids. The IR peak at $1715 \mathrm{~cm}^{-1}$ of potassium permanganate modified biomass is more intense than unmodified biomass. This peak belongs to the group of carboxylic acids (Jeon et al. 2002). Carboxyl groups of potassium permanganate modified biomass are increased. The sharp peaks at 1646 (A), 1650 (B), and $1652 \mathrm{~cm}^{-1}$ (C) can be attributed to $\mathrm{C}=\mathrm{O}$ stretching vibrations of primary amides. The bands present at 1539 (A), 1550 (B), and $1538 \mathrm{~cm}^{-1}$ (C) indicate the presence of secondary amides (Silverstein, RM. Webster X. F. 2005). The peaks at 1394 (A) $\mathrm{cm}^{-1}, 1375 \mathrm{~cm}^{-1}$ (B), and $1378 \mathrm{~cm}^{-1}$ may represent $-\mathrm{CH}_{3}$ wagging (Kumar and Min 2011). Stretching vibration peaks of $\mathrm{C}-\mathrm{N}$ were observed at $1241 \mathrm{~cm}$ ${ }^{1}(\mathrm{~A}), 1250 \mathrm{~cm}^{-1}$ (B), and $1242 \mathrm{~cm}^{-1}$ (C) (Silverstein, RM. Webster X. F. 2005). The strong peaks at $1026 \mathrm{~cm}^{-1}$, $1031 \mathrm{~cm}^{-1}$, and $1038 \mathrm{~cm}^{-1}$ could be assigned to $-\mathrm{CN}$ stretching vibration (Bai and Abraham 2002). Except for the

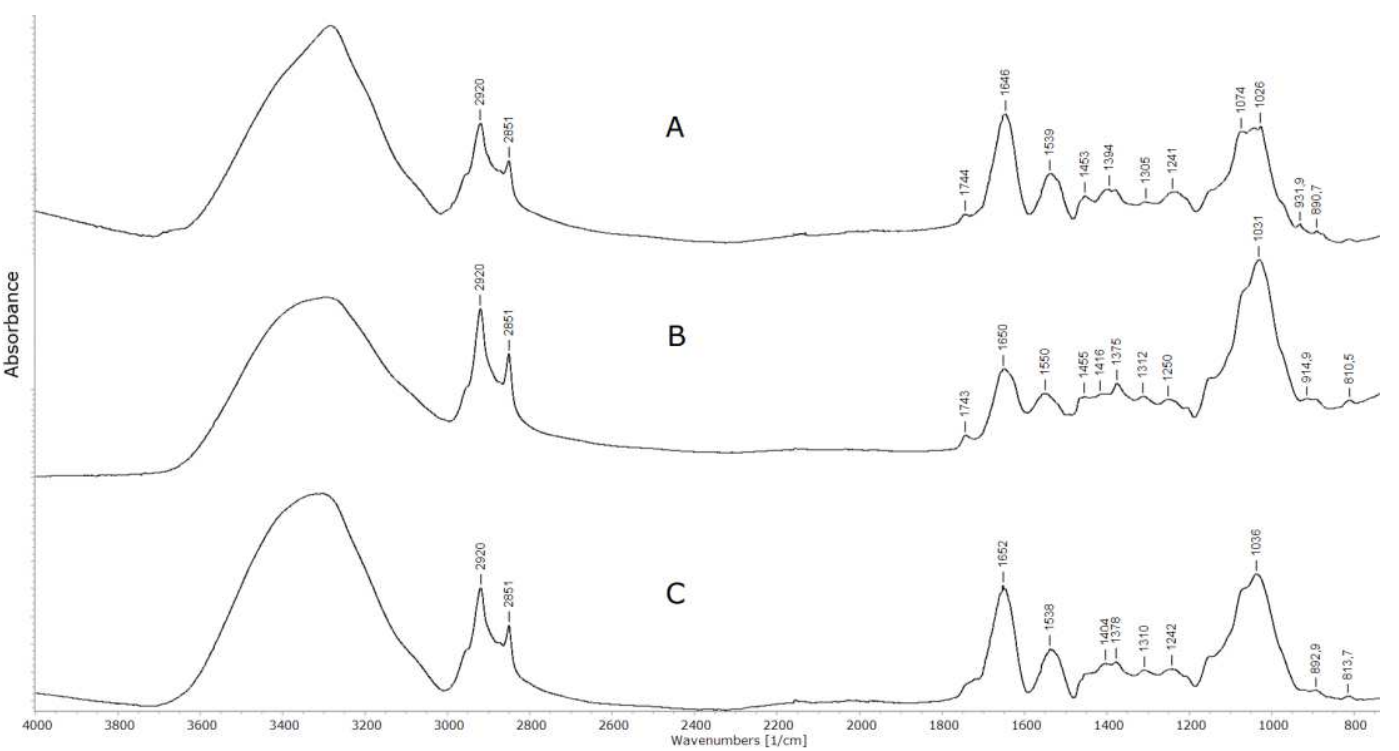

184 Figure 2. FTIR spectra of Unmodified (A), CTAB modified (B), and $\mathrm{KMNO}_{4}(\mathrm{C})$ modified biomass

\subsection{Effect of pH and modification methods}

The $\mathrm{pH}$ value of the medium is one of the important parameters in adsorption. In this study, the effect of $\mathrm{pH}$ on adsorption of RBBR was investigated in the range from 2-7 using unmodified, CTAB and potassium permanganate modified yeast biomass. As depicted in Figure 3, all three adsorbents showed maximum Remazol Brilliant Blue R adsorption at $\mathrm{pH} 2-3$ (CTAB modified biomass: $103 \mathrm{mg} / \mathrm{g}$, potassium permanganate modified biomass: $102 \mathrm{mg} / \mathrm{g}$, unmodified biomass: $102.89 \mathrm{mg} / \mathrm{g}$. RBBR adsorption capacity of all adsorbents decreased significantly when the $\mathrm{pH}$ value increased from 3 to 4 . 
In water, $\mathrm{RBBR}$ dye dissociates as $\mathrm{X}-\mathrm{SO} 3 \mathrm{Na} \rightleftarrows \mathrm{X}-\mathrm{SO}_{3}{ }^{-}+\mathrm{Na}^{+}$(Mate and Mishra 2020).

At low $\mathrm{pH}$ values, functional groups on the cell protonated and attain a positive charge (Ergene et al. 2009). As a result, the negatively charged RBBR dye is adsorbed by the positively charged modified and unmodified biomass due to electrostatic interactions. At high $\mathrm{pH}$ values, RBBR adsorption has decreased due to excess $\mathrm{OH}^{-}$ions competing with anionic dye and electrostatic repulsion (Silva et al. 2016).

In this study, where the effect of two different chemical modification methods on RBBR biosorption was examined, it was found that modified and unmodified yeast biomass did not cause a difference in terms of RBBR biosorption at $\mathrm{pH} 2$ and 3 values at which maximum adsorption was observed. Therefore, further studies will be continued with unmodified biomass.

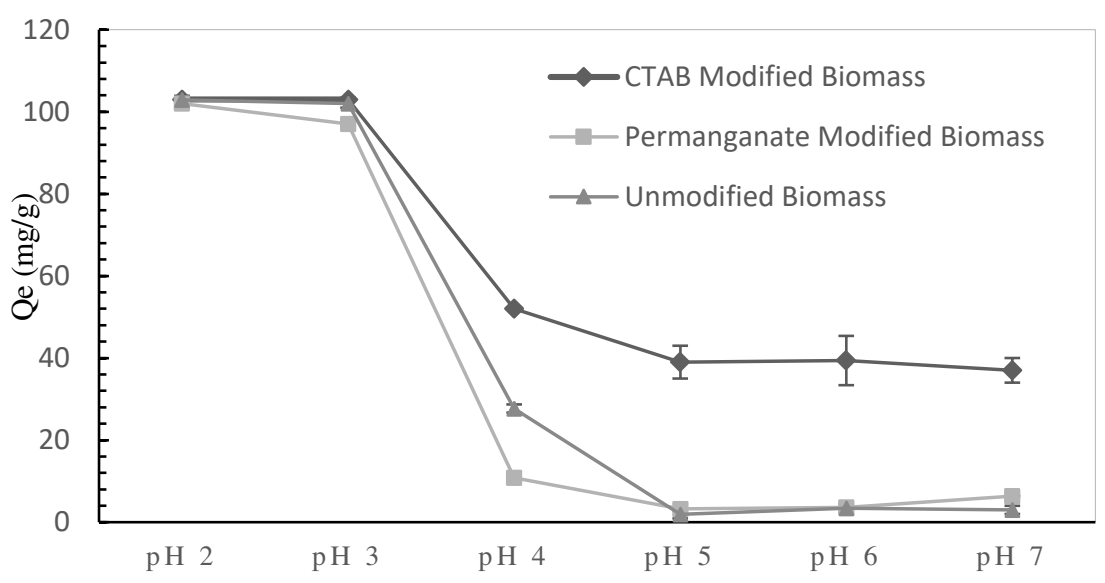

Figure 3. Effect of $\mathrm{pH}$ on biosorption of RBBR dye $\left(\mathrm{C}_{\mathrm{i}}: 100 \mathrm{mg} / \mathrm{mg} / \mathrm{L}, 25^{\circ} \mathrm{C}, 150 \mathrm{rpm}\right)$

\section{3. Effect of initial dye concentration on adsorption}

The effect of initial RBBR dye concentration on biosorption was studied by altering dye concentration from 25 to $175 \mathrm{mg} / \mathrm{L}$. The dye adsorption capacity was increased with increasing dye concentration up to $150 \mathrm{mg} / \mathrm{L}$. The maximum adsorption value $(110.96 \mathrm{mg} / \mathrm{g}$ ) was observed at a concentration of $150 \mathrm{mg} / \mathrm{L}$ (Fig. 4). The concentration of RBBR dye at higher than $150 \mathrm{mg} / \mathrm{L}$, adsorption efficiency was decreased. At higher RBBR concentration availability of active adsorption sites decreased, reducing dye adsorption efficiency (Mate and

234 Mishra 2020). 


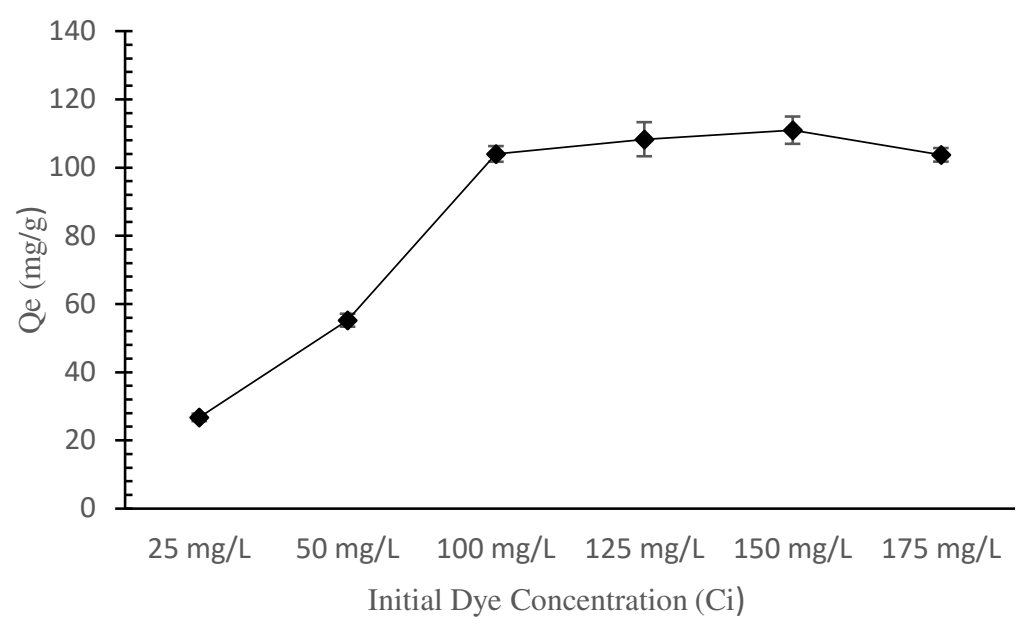

Figure 4. Effect of initial RBBR dye concentration on biosorption ( $\left.\mathrm{pH}: 2,25^{\circ} \mathrm{C}, 150 \mathrm{rpm}\right)$

\subsection{Effect of biosorbent dosage on adsorption}

Dosage of biosorbent is an important variable to determine the effective removal of pollutants. With increasing biomass dosage, the removal efficiency of RBBR dye increases up to a certain limit (Fig. 5). The maximum removal rate, for RBBR dye $(99.43 \%)$ dye was attained at $1500 \mathrm{mg} / \mathrm{L}$ biosorbent dosage. As the biomass dose increases, dye removal increases due to the adsorbent surface area, and active sites to which RBBR dye can bind will increase (Ratnamala et al. 2012).

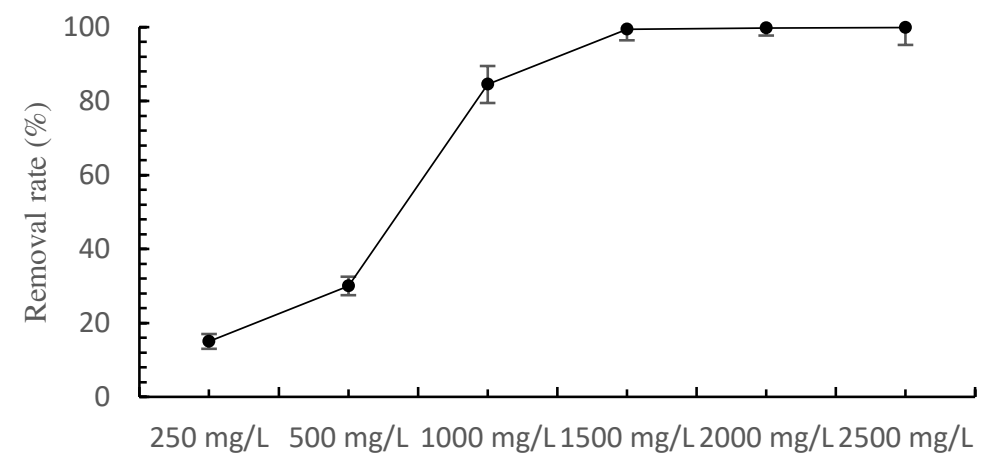

Amount of biomass

Figure 5. Effect of biomass dose on the removal of RBBR dye $\left(\mathrm{C}_{\mathrm{i}}: 150 \mathrm{mg} / \mathrm{L}, \mathrm{pH}: 2,25^{\circ} \mathrm{C}, 150 \mathrm{rpm}\right)$

\subsection{Effect of temperature and contact time}

Temperature is an important factor affecting the adsorption capacity. If adsorption capacity increases with increasing temperature indicate that the adsorption is endothermic. Conversely, if the adsorption capacity decreases with increasing temperature, the adsorption is exothermic (Yagub et al. 2014). As depicted in figure 6, the biosorption capacity of unmodified biomass increases with the increasing temperature that corresponds to an endothermic process. 
The diffusion rate of dye in the inner pores of the adsorbent increases with temperature (Ratnamala et al. 2012). Additionally, at higher temperatures, more RBBR dye molecules have enough energy to interact with the active sites of the adsorbent (Ahmad et al. 2014). In previous studies, adsorption of RBBR dye was defined as an endothermic process (Ada et al. 2009; Mafra et al. 2013).

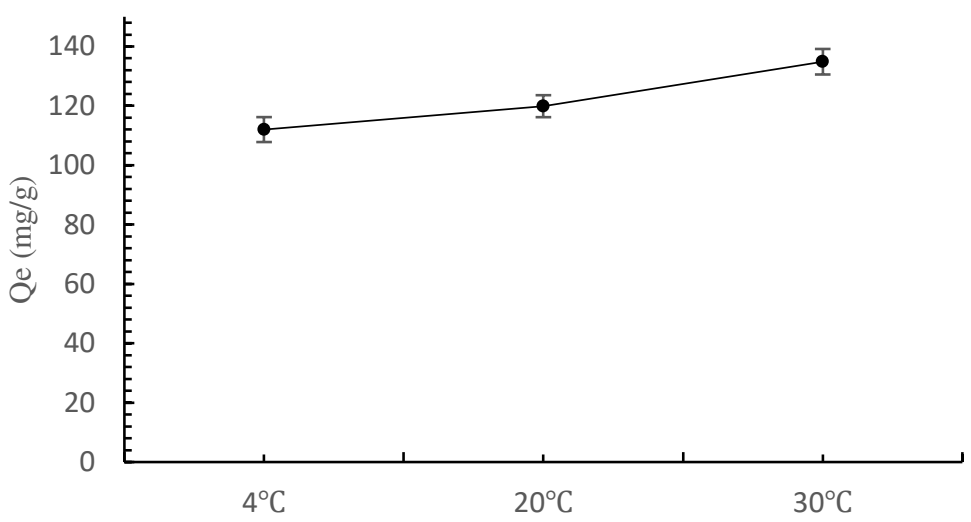

Temperature

\subsection{Isotherms}

The Langmuir isotherm model explained the monolayer and homogenous adsorption with limited active sorption sites on the sorbent. Thus, sorption sites are covered once by adsorbate and no adsorption will occur thereafter

Figure 6. Effect of temperature on biosorption of Remazol Brilliant Blue $\mathrm{R}\left(\mathrm{C}_{\mathrm{i}}: 150 \mathrm{mg} / \mathrm{L}, \mathrm{pH}: 2,150 \mathrm{rpm}\right)$

When the biosorption of RBBR against time is considered, it is seen that almost $50 \%$ of the dye is absorbed within the first 15 minutes (Fig. 7). It is seen that biosorption takes place in two stages: in the first stage, dye molecules are adsorbed rapidly due to the abundant active binding sites of the biosorbent, in the second stage the rate of biosorption decreases, and the removal efficiency decreases.

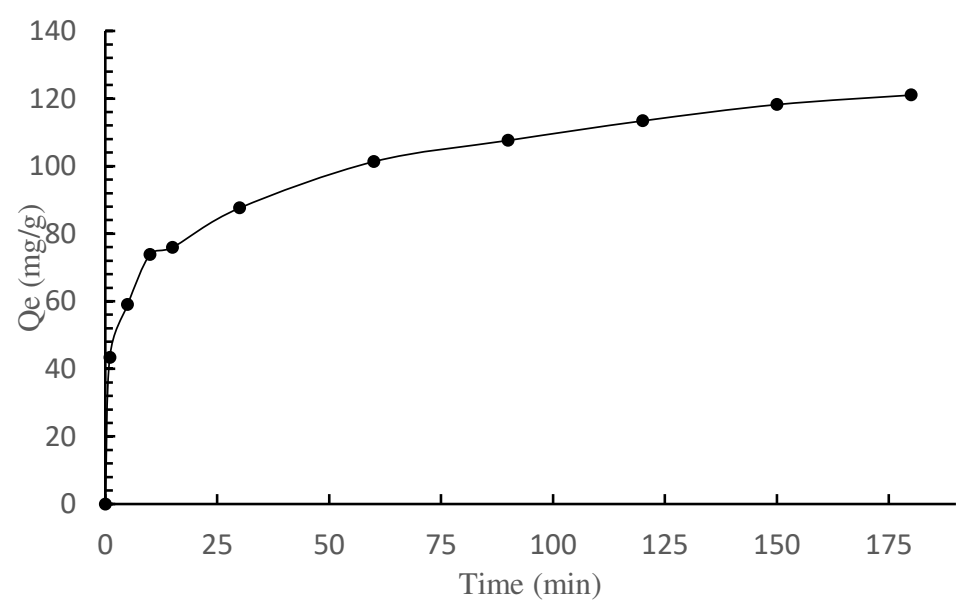

Figure 7. Effect of contact time on biosorption of RBBR dye $\left(\mathrm{C}_{\mathrm{i}}: 150 \mathrm{mg} / \mathrm{L}, \mathrm{pH}: 2,150 \mathrm{rpm}\right)$ (Hussain et al. 2021). As depicted in figure 8, the plot of experimental $1 / \mathrm{Q}_{\mathrm{e}} \mathrm{vs} 1 / \mathrm{C}_{\mathrm{e}}$ fits well linear Langmuir adsorption model $\left(R^{2}=0.991\right.$ and adjusted $\left.R^{2}=0.989, \mathrm{~K}_{\mathrm{L}}=0.00027\right)$. 




Figure 8. Linearized Langmuir plots of RBBR biosorption ( $\left.\mathrm{pH}: 2,25^{\circ} \mathrm{C}, 150 \mathrm{rpm}\right)$

The theoretically calculated Qmax value $(124.68 \mathrm{mg} / \mathrm{g})$ was found to be higher than the experimental values. $R_{L}$ values for all initial dye concentrations in the range of $0<\mathrm{RL}<1$ which indicates that the adsorption model is favorable for dye (Table 1).

290 A previous study of zinc oxide powders, Z075 and Z300 showed theoretical maximum adsorption capacity values $38.9 \mathrm{mg} / \mathrm{g}$ and $89.3 \mathrm{mg} / \mathrm{g}$, respectively (Ada et al. 2009). Immobilized green algae Scenedesmus quadricauda biomass obeyed Langmuir isotherm, as well (Ergene et al. 2009)

Table 1. $R_{L}$ values of the Langmuir isotherm at different initial dye concentrations at $25^{\circ} \mathrm{C}$.

\begin{tabular}{lc}
\hline Initial Dye Concentration $\left(\mathrm{C}_{\mathrm{i}}\right)$ & $\mathrm{R}_{\mathrm{L}}$ \\
$25 \mathrm{mg} / \mathrm{L}$ & 0,993 \\
$50 \mathrm{mg} / \mathrm{L}$ & 0.987 \\
$100 \mathrm{mg} / \mathrm{L}$ & 0.974 \\
$125 \mathrm{mg} / \mathrm{L}$ & 0.967 \\
$150 \mathrm{mg} / \mathrm{L}$ & 0.961 \\
$175 \mathrm{mg} / \mathrm{L}$ & 0.955 \\
\hline
\end{tabular}

The Freundlich isotherm is a commonly used model for adsorption studies. The Freundlich adsorption isotherm is

306 valid for heterogeneous adsorption surface and interaction between adsorbate molecules (Alver and Metin 2012).

307 The experimental data of this study is better for the Langmuir adsorption model than the Freundlich adsorption 308 model $\left(R^{2}=0.804\right.$, Adjusted $\mathrm{R}^{2}=0.752$, Fig. 9). 


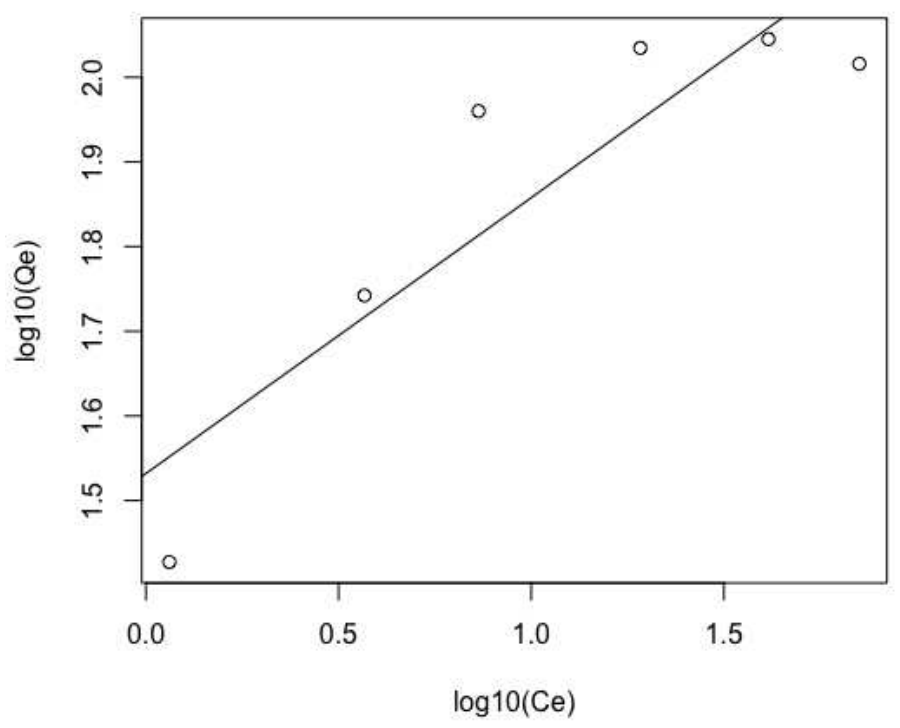

Figure 9. Freundlich isotherm of RBBR dye biosorption

Adsorption of RBBR dye with activated carbon prepared from pinang frond better fit Freundlich adsorption model than Langmuir adsorption model [34]. A previous study reported that adsorption of RBBR obeyed both Langmuir and Freundlich models (Aksu and Dönmez 2003). In this study adsorption RBBR dye onto unmodified Yarrowia lipolytica biomass better fit Langmuir isotherm $\left(R^{2}=0.991\right)$ than Freundlich isotherm $\left(R^{2}=0.804\right)$.

\subsection{Kinetics}

Kinetic adsorption data of Reactive Brilliant Blue R on biomass were considered using two kinetic models: pseudofirst order and pseudo-second-order. Pseudo-second-order kinetic model gives a higher $R^{2}(0.995)$ value than the first-order kinetic model $\left(R^{2}: 0.943\right)$. The low correlation coefficient value $(\mathrm{R} 2=0.8911-0.9478)$ indicates that the pseudo-first-order kinetic model does not fit the experimental value well. Figure 10 shows the assumed pseudosecond-order model for adsorption of Reactive Brilliant Blue R (RBBR) dye on unmodified biomass with linear regression coefficient value $R^{2}$ as 0.995 (slope:0.0082, intercept: 0.0551 ). A high $\mathrm{R}^{2}$ value indicates that this kinetic model has a good correlation and the theoretical $q_{e}$ value is consistent with the experimental qe value(Ahmad et al. 2014).

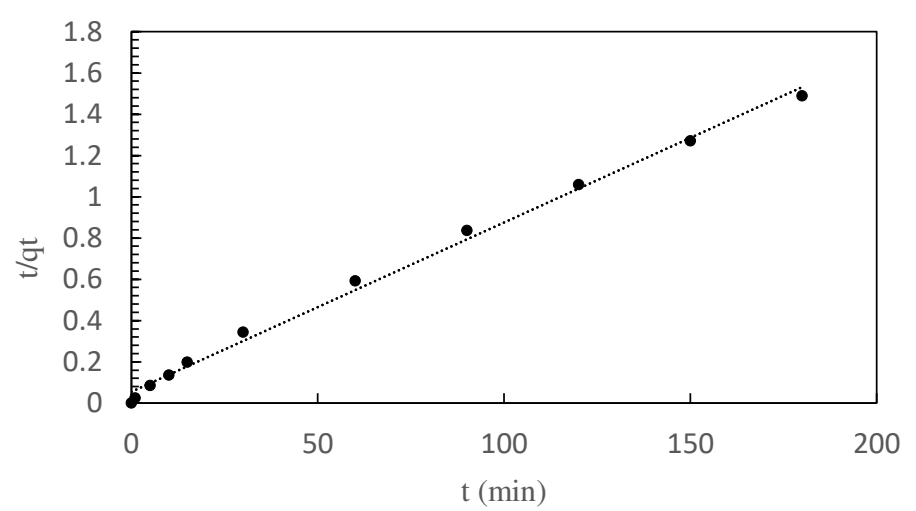

Fig 10. Pseudo-second-order kinetic model for RBBR dye biosorption 
The theoretical amount of RBBR that can be adsorbed by unmodified biomass, $q_{e}$ was calculated as $121.57 \mathrm{mg} / \mathrm{g}$ from the slope of the linear line. This value was found as $121 \mathrm{mg} / \mathrm{g}$ experimentally. The reaction rate constant for the pseudo-second-order adsorption process was calculated as $1.22 \times 10^{-3} \mathrm{~g} / \mathrm{mg}$ min. from an intercept.

\section{References}

Ada K, Ergene A, Tan S, Yalçın E (2009) Adsorption of Remazol Brilliant Blue R using ZnO fine powder: Equilibrium, kinetic and thermodynamic modeling studies. Journal of hazardous materials 165:637-644

Ahmad MA, Herawan SG, Yusof AA (2014) Equilibrium, Kinetics, and Thermodynamics of Remazol Brilliant Blue R Dye Adsorption onto Activated Carbon Prepared from Pinang Frond. ISRN Mechanical Engineering 2014:1-7. https://doi.org/10.1155/2014/184265

Aksu Z, Dönmez G (2003) A comparative study on the biosorption characteristics of some yeasts for Remazol Blue reactive dye. Chemosphere 50:1075-1083

Alver E, Metin AÜ (2012) Anionic dye removal from aqueous solutions using modified zeolite: Adsorption kinetics and isotherm studies. Chemical Engineering Journal 200-202:59-67. https://doi.org/10.1016/j.cej.2012.06.038

Ayub S, Mohammadi AA, Yousefi M, Changani F (2019) Performance evaluation of agro-based adsorbents for the removal of cadmium from wastewater. Desalination and Water Treatment. https://doi.org/10.5004/dwt.2019.23455

Bai RS, Abraham TE (2002) Studies on enhancement of Cr ( VI ) biosorption by chemically modified biomass of Rhizopus ni g ricans. 36:1224-1236

El-Naas MH, Alhaija MA (2013) Modelling of adsorption processes. Mathematical Modelling 579-600

Ergene A, Ada K, Tan S, Katircioğlu H (2009) Removal of Remazol Brilliant Blue R dye from aqueous solutions by adsorption onto immobilized Scenedesmus quadricauda: Equilibrium and kinetic modeling studies. Desalination 249:1308-1314. https://doi.org/10.1016/j.desal.2009.06.027

Fan T, Liu Y, Feng B, et al (2008) Biosorption of cadmium(II), zinc(II), and lead(II) by Penicillium simplicissimum: Isotherms, kinetics, and thermodynamics. Journal of Hazardous Materials 160:655-661. https://doi.org/10.1016/j.jhazmat.2008.03.038

Freundlich H (1907) Über die Adsorption in Lösungen. Zeitschrift für Physikalische Chemie 57U:385470. https://doi.org/10.1515/zpch-1907-5723

Gad HMH, El-Sayed AA (2009) Activated carbon from agricultural by-products for the removal of Rhodamine-B from aqueous solution. Journal of Hazardous Materials 168:1070-1081. https://doi.org/10.1016/j.jhazmat.2009.02.155

Gon??alves FAG, Colen G, Takahashi JA (2014) Yarrowia lipolytica and its multiple applications in the biotechnological industry. The Scientific World Journal 2014:. https://doi.org/10.1155/2014/476207

GONG R, SUN Y, CHEN J, et al (2005) Effect of chemical modification on dye adsorption capacity of peanut hull. Dyes and Pigments 67:175-181. https://doi.org/10.1016/j.dyepig.2004.12.003

Hasan Z, Jeon J, Jhung SH (2012) Adsorptive removal of naproxen and clofibric acid from water using metal-organic frameworks. Journal of Hazardous Materials 209-210:151-157. https://doi.org/10.1016/j.jhazmat.2012.01.005 
Ho YS, McKay G (1999) Pseudo-second order model for sorption processes. Process Biochemistry 34:451465. https://doi.org/10.1016/S0032-9592(98)00112-5

Huang J, Liu D, Lu J, et al (2016) Colloids and Surfaces A : Physicochemical and Engineering Aspects Biosorption of reactive black 5 by modified Aspergillus versicolor biomass : Kinetics, capacity and mechanism studies. Colloids and Surfaces A: Physicochemical and Engineering Aspects 492:242-248. https://doi.org/10.1016/j.colsurfa.2015.11.071

Hussain S, Kamran M, Khan SA, et al (2021) Adsorption, kinetics and thermodynamics studies of methyl orange dye sequestration through chitosan composites films. International Journal of Biological Macromolecules 168:383-394. https://doi.org/10.1016/j.ijbiomac.2020.12.054

Jeon C, Park JY, Yoo YJ (2002) Characteristics of metal removal using carboxylated alginic acid. Water Research 36:1814-1824. https://doi.org/10.1016/S0043-1354(01)00389-X

Jianlong W (2002) Biosorption of copper ( II ) by chemically modified biomass of Saccharomyces cere 6 isiae. 37:847-850

Jung C, Park J, Lim KH, et al (2013) Adsorption of selected endocrine disrupting compounds and pharmaceuticals on activated biochars. Journal of Hazardous Materials. https://doi.org/10.1016/j.jhazmat.2013.10.033

Kumar KV, Ramamurthi V, Sivanesan S (2006) Biosorption of malachite green, a cationic dye onto Pithophora sp ., a fresh water algae. 69:102-107. https://doi.org/10.1016/j.dyepig.2005.02.005

Kumar NS, Min K (2011) Phenolic compounds biosorption onto Schizophyllum commune fungus: FTIR analysis, kinetics and adsorption isotherms modeling. Chemical Engineering Journal 168:562571. https://doi.org/10.1016/j.cej.2011.01.023

Lagergren S (1898) About the theory of so-Lagergren, S. (1898). About the theory of so-called adsorption of solid substance. Handlinger. https://doi.org/10.4236/ss.2014.52008called adsorption of solid substance. Handlinger. https://doi.org/10.4236/ss.2014.52008

Langmuir I (1918) The adsorption of gases on plane surfaces of glass, mica and platinum. Journal of the American Chemical Society 40:1361-1403. https://doi.org/10.1021/ja02242a004

Liu K, Li H, Wang Y, et al (2015) Adsorption and removal of rhodamine B from aqueous solution by tannic acid functionalized graphene. Colloids and Surfaces A: Physicochemical and Engineering Aspects 477:35-41. https://doi.org/10.1016/j.colsurfa.2015.03.048

Luo F (2006) Biosorption of lead ion by chemically-modified biomass of marine brown algae Laminaria japonica. 64:1122-1127. https://doi.org/10.1016/j.chemosphere.2005.11.076

Mafra MR, Igarashi-Mafra L, Zuim DR, et al (2013) Adsorption of remazol brilliant blue on an orange peel adsorbent. Braz J Chem Eng 30:657-665. https://doi.org/10.1590/S0104-66322013000300022

Mate CJ, Mishra S (2020) Synthesis of borax cross-linked Jhingan gum hydrogel for remediation of Remazol Brilliant Blue R (RBBR) dye from water: Adsorption isotherm, kinetic, thermodynamic and biodegradation studies. International Journal of Biological Macromolecules 151:677-690. https://doi.org/10.1016/j.ijbiomac.2020.02.192

Mohamed SH, El-gendy AA, Abdel-kader AH, El-ashkar EA (2015) Removal of heavy metals from water by adsorption on chitin derivatives. 7:275-283

Novotnýeněk, Rawal B, Bhatt M, et al (2001) Capacity of Irpex lacteus and Pleurotus ostreatus for decolorization of chemically different dyes. Journal of Biotechnology 89:113-122. https://doi.org/10.1016/S0168-1656(01)00321-2

Rao JR, Viraraghavan T (2002) Biosorption of phenol from an aqueous solution by Aspergillus niger biomass. Bioresource Technology 85:165-171. https://doi.org/10.1016/S0960-8524(02)00079-2 
Ratnamala GM, Shetty KV, Srinikethan G (2012) Removal of Remazol Brilliant Blue Dye from DyeContaminated Water by Adsorption Using Red Mud: Equilibrium, Kinetic, and Thermodynamic Studies. Water Air Soil Pollut 223:6187-6199. https://doi.org/10.1007/s11270-012-1349-4

Salvi NA, Chattopadhyay S (2016) Biosorption of Azo dyes by spent Rhizopus arrhizus biomass. Applied Water Science. https://doi.org/10.1007/s13201-016-0417-0

Saratale GD, Chang J (2011) Bacterial Decolorization and Degradation of Azo Dyes : A Review. Journal of the Taiwan Institute of Chemical Engineers 42:138-157. https://doi.org/10.1016/j.jtice.2010.06.006

Silva TL, Ronix A, Pezoti O, et al (2016) Mesoporous activated carbon from industrial laundry sewage sludge: Adsorption studies of reactive dye Remazol Brilliant Blue R. Chemical Engineering Journal 303:467-476. https://doi.org/10.1016/j.cej.2016.06.009

Silverstein, RM. Webster X. F. KJD (2005) Spectrometric Identification of Organic Compounds 7th Edition

Trivedi KN, Boricha AB, Bajaj HC, Jasra R V. (2009) Adsorption of Remazol Brilliant Blue R dye from water by polyaluminum chloride. Rasayan Journal of Chemistry

Xiong XJ, Meng XJ, Zheng TL (2010) Biosorption of C.I. Direct Blue 199 from aqueous solution by nonviable Aspergillus niger. Journal of Hazardous Materials 175:241-246. https://doi.org/10.1016/j.jhazmat.2009.09.155

Yagub MT, Sen TK, Afroze S, Ang HM (2014) Dye and its removal from aqueous solution by adsorption: A review. Advances in Colloid and Interface Science 209:172-184. https://doi.org/10.1016/j.cis.2014.04.002

Zheng Y, Cheng B, Fan J, et al (2021) Review on nickel-based adsorption materials for Congo red. Journal of Hazardous Materials 403:123559. https://doi.org/10.1016/j.jhazmat.2020.123559 